\title{
The Benefits of Integrating the Learn English Grammar Application into the Saudi EFL Pre-Intermediate Preparatory Year Classroom
}

\author{
Nada Gamlo \\ English Language Institute \\ King Abdul-Aziz University, Jeddah, Saudi Arabia \\ E-mail: ngamlo@kau.edu.sa
}

Received: January 9, 2019 Accepted: January 30, 2019 Published: February 2, 2019

doi:10.5296/ijele.v7i1.14310 URL: https://doi.org/10.5296/ijele.v7i1.14310

\begin{abstract}
This study examines the benefits of using the mobile application Learn English Grammar for English as a Foreign Language (EFL) with students attending King Abdul Aziz University in Saudi Arabia. The participants consisted of fifty-two female pre-intermediate level students in the foundation year program, with twenty-seven assigned to the experimental group and twenty-five forming the control. Both groups undertook a pre-test to ensure an equal level of skill and a post-test to establish any statistically significant differences in their grammatical attainment. The findings revealed a significant difference at $p=0.006$ in favor of the experimental group. The students completed a questionnaire, which revealed a positive attitude towards the application, while the teacher's reflective notes indicated that it created an exciting and motivating learning environment. This study contributes to the area of mobile learning in EFL class rooms by highlighting the importance of mobile applications for both improving the classroom environment and facilitating students' language acquisition.
\end{abstract}

Keywords: Mobile learning, Technology, EFL, Mobile Applications, Attitudes, Learn English Grammar application, Classroom Activities, Engagements 


\section{Introduction}

Mobile learning (m-learning) has become a popular educational strategy, particularly in relation to English as a Foreign Language (EFL). Rodríguez et al. (2013: 1189) defined $\mathrm{m}$-Learning as "the use of mobile technologies for educational purposes". This has led to research concerning the utilization of smartphones to activate m-learning in EFL learning and teaching. The importance of using a smartphone as a tool of language learning relates to its function as a pocket device capable of being used at all times and in most locations. In addition, it offers variety of learning language applications ('apps'), including those designed for language learning, i.e. Busuu (Kétyi, 2013); My Word Book; Johnny Grammar's Quiz Master; Sixty Second Word Challenge (Rodríguez et al., 2013)

There is currently a limited amount of research investigating the benefits of mobile phones and applications for learning grammar, in particular for acquiring vocabulary and improving listening skills (Wang \& Smith, 2013). EFL learners attending the foundation level at ELI at KAU have expressed a number of concerns relating to the acquisition of grammatical structures, stating that they find studying grammar challenging. Furthermore, grammatical errors frequently appear in their written work, as well as their spoken language and responses to quizzes, all of which have an impact on their final scores. This is significant, as students are anxious to achieve the grades that will enable them to specialize in one of their preferred majors, which tends to require a high score in English. Due to its essential role in EFL learning, it is important to improve the grammatical performance of students. Mart (2013) stated that mastering grammatical skills results in an effective learner, who is able to correctly convey comprehensible messages in both speaking and writing, highlighting that the teaching of grammar is complex, while being vital for meaningful learning outcomes. However, despite the opportunities offered to EFL learners by m-learning, the use of smartphone applications remains restricted in KAU. This current study was undertaken in response to both the limited research into the use of mobile application for grammar learning, and a desire to assist students to improve their grammatical skills.

The current study therefore focused on answering the following questions:

- Were there any statistically significant differences between the achievements of the experiment and control groups when it came to learning grammar?

- What were Saudi EFL female foundation year students' perceptions of the integration of the Learn English Grammar application in the classroom for the learning of grammar?

- What was the teachers' reflective view of integrating the Learn English Grammar application into their teaching?

\section{Literature Review}

2.1. The use of mobile learning applications as a language learning tool 
It is generally accepted that mobile phones are now central to contemporary life. Wireless (Wi-Fi) connections are made available in most universities, both for staff and students. In addition, the majority of instructors and students possess smartphones for personal use, including making calls, texting, socializing and the checking and sending of emails. However, there is also considerable awareness of the ability to use mobile phones features for education in general and English learning and teaching in particular.

Chen (2017) argued that many of the different perceptions of mobile learning can encourage EFL/ESL teachers and learners to consider the use of mobile applications to assist in the learning of English. This highlights the view that the potential effectiveness of mobile phone applications in comparison to face-to-face instructions can lead to their wider use in EFL learning and teaching. Liu and $\mathrm{He}$ (2014) stressed the accelerated advancement of mobile English learning applications utilizing a variety of different media (i.e. video, audio, pictures and animation) to create a broad range of useful digital materials. Gafni et al. (2017:304) suggested that mobile applications can offer mobility and can connect learners to significant real context. Furthermore, Alshammari et al. (2016) noted that both students and teachers have been found to use the WhatsApp application for language learning, in particular to facilitate the circulating of information between students and teachers, language leaning resources and practice activities related to learning materials.

EFL learners can explore a number of different learning experiences using mobile applications, i.e. SMS, YouTube, cameras, and dictionaries. Suwantarathip and Orwiwatnakil (2015) found that the use of SMS improved the learning of vocabulary among first year university students, thus confirming that SMS can be successfully employed for learning purposes. Alwehaibi (2015) recommended the integration of YouTube as a useful resource for EFL college students, in particular in relation to classroom instructions. Kabooha (2016) also examined the use of YouTube as a tool for learning vocabulary, revealing significant improvement in EFL students' acquisition of vocabulary. Furthermore, Ariffin and Idris (2016) stated that their participants employed mobile phone cameras to take pictures of their completed assignments. In addition, Nalliveettil and Alenazi (2016) examined the impact of mobile phones on Saudi male English and literature major students, identifying that most of these undergraduates found the use of dictionary applications on their mobile phones highly beneficial.

This should encourage full awareness of the potential of mobile phones, however, some learners and teachers still face a number of some obstacles in integrating mobile phones for the learning or teaching of English. Ariffin and Idris (2016) found that a lack of knowledge of the learning functions of mobile phones among some Malaysian teacher trainees resulted in many preferring face-to- face instructions. The authors also recorded that technical issues and the high cost of mobile phones proved obstacles to the utilization of mobile learning in EFL teaching and learning. Obstacles and enablers to mobile learning are beyond the scope of this current study, although some are mentioned briefly in relation to students' perceptions of the Learn English Grammar application.

Mobile phone language learning applications have now become popular among most learners 
and instructors. There are many free language learning applications, made available for users in Google stores (Hossain, 2018). Nushi and Iqbali's (2018) review of the free application 50Languages suggested that, regardless of its shortcomings, it was capable of offering effective support for a second language learning and thus assisting learners to acquire the target language in a short period of time. Al-Wasy and Mahdi (2016) conducted an experiment in Saudi Arabia exploring the impact of an application known as White Smoke on EFL students' self-editing and other language skills. The authors found that the students recorded an improvement in self-editing, grammar and punctuation, but that no difference was observed when it came to spelling and capitalization.

Students' take-up of mobile learning tends to depend on their beliefs concerning its benefits. Costa and Han (2017) examined the impact of WhatsApp activities on foundation year EFL learners in Turkey, concluding that students developed an increasingly positive attitude, believing that the application's activities were helpful in learning new vocabulary, as well as being a convenient tool for learning English.

\subsection{Advantages of introducing $m$-learning into the classroom environment}

Learners using mobile phones for learning purposes face a number of issues, including technical problems and is sues related to cost, lack of knowledge of learning applications, and feeling safe with traditional instruction. In Malayisia, Ariffin and Idris (2016) found that teacher trainees believed some students experienced difficulties in purchasing smartphones and accessing wireless connections, and would thus prefer to receive face-to-face instructions. In addition, Gafni et al. (2017:313) found that students can be distracted when receiving calls and SMS notifications on their mobiles. However, many studies have demonstrated that learning applications for mobile phones can result in the classroom becoming a pleasant and productive experience (Alshammari et al., 2017; Ariffin \& Idris, 2016; Gafni et al., 2017; Hossain, 2018; Nushi \& Eqbali, 2018; Rajayi et al., 2018; Suwantarathip \& Orawiwatnakul, 2015).

A number of studies have argued that mobile EFL learning applications can provide learners with authentic learning content. Kabooha and Elyas (2018) found EFL Saudi students and teachers displayed a positive attitude towards the use of YouTube (including the integration of video clips) in reading classes. Furthermore, teachers found it to be a useful tool, due to its ability to provide a variety of authentic materials. Nushi and Eqbali (2018:102) found the 50Languages application proved highly effective for learning a second language, particularly when it came to correct pronunciation, particularly as it employs a native speaker for all its content. Similarly, Rajayi et al. (2018), found that integrating the Kik application into EFL learning enabled learners to both acquire new words and use them in the correct context. Ariffin and Idris (2016) concluded that enabling students to use their mobile to create multimedia activities for was successful in relation to various subjects. The authors added that students proved more motivated and engaged, and achieved improved learning outcomes, in comparison to students taught by means of a traditional strategy. In addition, the authors confirmed that students developed technical skills, which could be observed in the quality of creative digital videos they created. 
It can be argued that using mobile applications for EFL learning can facilitate autonomous learning (Gafni et al., 2017), resulting in students feeling more confident in "shar(ing) their proficiency with their friends through the same device" (Hossain, 2018:2). Alshammari et al. (2016) found that using WhatsApp created independent learners, able to identify additional resources capable of matching their needs and so develop their learning. This can create a successful learning environment, i.e. the aim of any learning process. It can also be argued that instructors should control the use of mobile application to ensure they become an effective EFL learning tool. Suwanlatathip and Orawiwatnakul (2015) argued that, although the majority of teachers found mobile phones to be somewhat distracting, they can, when used effectively, create meaningful tasks. Kabooha (2016), in her study of the impact of using movies in EFL classrooms, argued that, when selecting films, instructors should take into account the proficiency level of their students.

The above review of literature led the current researcher to consider that a study examining the impact of integrating Learn English Grammar app on EFL Saudi grammar learning would make a vital contribution to the literature.

The following section introduces the methodology implemented in this study.

\section{Methodology}

\subsection{Research Methods}

The study adopted a quantitative and qualitative approach to answer the research questions. In addition, it applied a pre-test and post-test control group research design. Two classes were selected, one being randomly assigned to form the experimental group and the other the control group. During the study, experimental group was exposed to the Learn English Grammar application, while the control group was taught using conventional teaching strategies. In order to ensure the equality of both groups, all students undertook a pre-test containing basic grammatical structures one week prior to the experiment and both groups took a post-test following the experiment, i.e. in week six of the module. The purpose of the post-test was to compare the grammatical performance of the two groups, in order to establish the presence of any significant differences. In addition, a questionnaire was utilized at the end of the experiment to explore the perceptions of the experiment group when it came to the benefits of the Learn English Grammar application. Moreover, the teachers of both groups were requested to write their reflections concerning the effectiveness of the Learn English Grammar application, along with its impact on the performance of students in the experimental group. The purpose of acquiring the teachers' reflections was to obtain a more vivid and critical picture of the reaction of students in the classroom.

\subsection{Participants}

The participants in this study were fifty-two female pre-intermediate level students in the foundation year program, aged between eighteen and twenty. The study sample was selected based on the convenience sampling method form of non-probability sampling (Cohen et al., 
2011: 155). Twenty-seven students were assigned to be the experimental group employing the mobile application, while the remaining twenty-five students formed the control group, taught in a traditional manner with no exposure the Learn English Grammar application. After they had been given information concerning the purpose of the study, all students were asked to sign informed consent forms to enable them to participate, while at the same time they were also reassured they were free to withdraw at any phase of the study. Two female teachers also participated.

\subsection{Data collection and procedures}

At the beginning of the experiment, a pre-test was administered to both the experimental and control groups. The pre-test was adopted from the placement test designed by the English language Institute at the university (ELI) and contained twenty multiple choice questions designed to verify the existence of any differences in grammatical performance between the two groups. The post-test was created by the researcher in relation to the contents covered in the students' books and, in order to ensure its validity, three teachers with experience in teaching the textbook were asked to check the content.

Both the experimental and the control group were taught identical grammatical structures in their textbook English Unlimited 3, including the following: present simple; past simple; present progressive; present perfect; past progressive; nouns; adjectives; will; might; may; some; any; future; used to.

The control group was taught by colleague of the researcher, who had volunteered to help in the experiment, while the pre-and post-test were both administered by the researcher. In addition, the experimental group was taught by the researcher, with students asked to upload the application Learn English Grammar before being given instructions on its use. The use of the application took place one hour each day for three days a week, for a period of four weeks. The experiment was conducted for the whole module (i.e. seven weeks), with the end of the first week being dedicated to administering the pre-test, in order to ensure the availability of all students, while the post-test for the experimental and control group, along with the questionnaire for the experimental group only, were conducted in week six. Week seven was generally taken up with final exams and grading.

The experimental group were supervised when undertaking the task. They were requested to open the application, click on the practice item and then select the pack, i.e. either elementary or intermediate. No pre-intermediate pack was available, but the existing packs included parallel content to that found in the students' text book.

Two teachers of the study were asked to write up their reflections at the end of the experiment, which were then read and analyzed, followed by a comparison considering the themes relating to the reactions of the students.

During week five of the experiment, both the experimental and control groups were asked to sit the pre-test (which consisted of twenty items), in order to determine the existence of any differences between the achievements of the two groups in relation to their grammar acquisition. 
A questionnaire was employed to explore the experimental group's perception of the Learn English Grammar application as a tool for learning grammar. The questionnaire was designed by the researcher and inspired by the literature, in order to answer the research questions. To ensure accurate responses, the questionnaire was translated into Arabic, i.e. the students' native tongue. Furthermore, both the English version and the translated version were checked for accuracy by three colleagues of the researcher, who were Arabic native speakers also fluent in English. A five-point Likert scale design was used. The questionnaire consisted of fifteen items and was broken down into three themes according to: (1) the usability of the application; (2) the effectiveness of the application; (3) and satisfaction.

\section{Results}

The present study applied quantitative analysis employing statistical analysis using IBM SPSS statistics version 20.0 to evaluate data, using an independent Samples T-test, to compare the pre-tests results of the control and experimental groups. The Independent Samples T-test was used due to the groups being normally distributed, to check if a significant difference could be identified between the grammatical knowledge of the two groups.

The Mann-Whitney parametric test was implemented to identify data not normally dis tributed, in order to determine the presence of any significant difference in the post-tests results between control and experimental group.

The post questionnaires were analyzed using SPSS using descriptive statistics.

The research questions were addressed in the following manner:

\subsection{A comparison of the pre-test results of the control and experiment groups}

For the pre-test between the control and experimental groups, both groups demonstrated equal variance $(p=0.664)$, but the mean grade difference $(0.501)$ was not statistically significant $(\mathrm{p}=0.516)$. This confirmed that the mean of the pre-test was approximately identical for both groups. Thus, the pre-test results of the control group ( $\mathrm{M}=14.76, \mathrm{SD}=2.681$ ) and the pre-test results of the experimental group $(\mathrm{M}=14.26, \mathrm{SD}=2.823)$ demonstrated no statistically significant differences in terms of their grammatical proficiency. This indicates that the groups were at the same level, which is important, to enable the experiment to examine the impact of the Learn English Grammar application on students' grammar proficiency (see Table 1).

Table 1. Pre-test Independent Sample t-test

\begin{tabular}{|l|c|c|c|c|c|}
\hline Group & $\mathrm{N}$ & Mean & Std. Deviation & $\mathrm{T}$ & $\mathrm{P}$ \\
\hline Control Group & 25 & 14.76 & 2.681 & .655 & 0.516 \\
Experimental & 27 & 14.26 & 2.823 & & \\
Group & & & & \\
\hline
\end{tabular}




\subsection{Comparison of the post-test results between the control and experimental groups}

The Mann-Whitney test was applied to compare the post-test results of the control and experimental groups, confirming that the difference between the two groups was statistically high at $\mathrm{p}=0.006$. The median of post-test was not identical for both groups, being higher in favor of the experiment group, i.e. Median=13.00 (11.00-13.00). The results revealed that the post-test results of the experimental group $(\mathrm{M}=13.37, \mathrm{SD}=3.265)$ were significantly higher than those of the control group $(\mathrm{M}=10.40, \mathrm{SD}=3.202)$ (see Table 2).

Table 2. Post-test Mann-Whitney test

\begin{tabular}{|l|l|l|l|l|l|l|c|}
\hline \multicolumn{1}{|c|}{ Group } & $\mathrm{N}$ & Mean & $\begin{array}{c}\text { Std. } \\
\text { Deviation }\end{array}$ & \multicolumn{3}{|c|}{ Percentiles } & $\mathrm{p}$ \\
\cline { 5 - 8 } & & & & 25 th & $\begin{array}{l}50 \text { th } \\
\text { (Median) }\end{array}$ & 75 th & \\
\hline $\begin{array}{l}\text { Control Group } \\
\text { Experimental }\end{array}$ & 25 & 10.40 & 3.202 & 7.500 & 11.00 & 13.00 & \\
Group & 27 & 13.74 & 3.265 & 11.00 & 13.00 & 17.00 & 0.006 \\
\hline
\end{tabular}

\subsection{Students' perceptions of integrating the Learn English Grammar application into the classroom}

This section introduces the analysis of the quantitative data from the post-experiment questionnaire, to explore the experimental group's perceptions of the impact of the Learn English Grammar application on their grammar skills. The questionnaire was broken down into three themes: (1) usability; (2) effectiveness; and (3) satisfaction. Each theme consisted of groups of questions to facilitate the statistical analysis. Descriptive statistics were employed to analyze the questionnaire items. The calculation of the inter-Item person correlation (see Table 3) revealed that all themes had a statistically significant correlation, with a total sum of the scale $\mathrm{p}$-value $<0.0005$, i.e. the scale was valid and had internal consistency with its themes.

Table 3. Validity test

\begin{tabular}{|l|r|l|}
\hline Usability & & \\
\hline Effectiveness & p-value & .00005 \\
\hline Satisfaction & p-value & .00005 \\
\hline
\end{tabular}

Cronbach's Alpha Coefficient was calculated to measure the internal consistency of the questionnaire items. As seen from Table 4 (below), the scale demonstrated good consistency 
as a measuring tool, i.e. Cronbach's Alpha $=0.838$.

Table 4. Reliability of the questionnaire

\begin{tabular}{|c|c|}
\hline $\begin{array}{c}\text { Cronbach's } \\
\text { Alpha }\end{array}$ & $\mathrm{N}$ of Items \\
\hline .838 & 15 \\
\hline
\end{tabular}

The statistics for the scale reveal that the overall response concerning the students' perceptions of the application was 'Agree', with a total weighted mean of 3.68. They agreed that the application was usable with a highest summated weighted mean of 4.10. This demonstrated that twenty-one students $(77.80 \%)$ 'Strongly Agreed' that they were able to practice grammar tasks using the Learn English Grammar application. Students agreed that the app was effective for learning grammar with summated weighted mean of 3.48 , with seventeen students $(63.00 \%)$ stating that they 'Strongly Agreed' that the Learn English Grammar application is an effective method of learning English grammar. Students also agreed that the app was satisfying, with a summated weighted mean of 3.46. Furthermore, eight students, (55. 60) 'Strongly Agreed' that they enjoyed using Learn English Grammar application (see Table 5). This result demonstrates that students held a positive attitude towards the use of Learn English Grammar app and that they perceived it as being beneficial for learning grammar.

As reported above, the usability theme was ranked with the highest weighted mean, followed secondly, by effectiveness and thirdly, satisfaction (see Table 6). This indicates that students experienced no obstacles when using the application and that they perceived it as being an effective tool for learning grammar. Moreover, they expressed a positive view of the application, noting that they had found it an enjoyable experience.

Table 5. Statistics of Scale Sorted Statements and Themes

\begin{tabular}{|c|c|c|c|c|c|c|c|c|c|c|c|c|}
\hline \multirow{2}{*}{ Statement } & \multicolumn{2}{|c|}{$\begin{array}{l}\text { Strongly } \\
\text { Disagree }\end{array}$} & \multicolumn{2}{|c|}{ Disagree } & \multicolumn{2}{|c|}{$\begin{array}{l}\text { Neither Agree/ } \\
\text { Nor Disagree }\end{array}$} & \multicolumn{2}{|c|}{ Agree } & \multicolumn{2}{|c|}{$\begin{array}{c}\text { Strongly } \\
\text { Agree }\end{array}$} & \multirow{2}{*}{$\begin{array}{l}\text { Weighted } \\
\text { Mean }\end{array}$} & \multirow{2}{*}{$\begin{array}{c}\text { Weighted Mean } \\
\text { Level }\end{array}$} \\
\hline & $n$ & $\%$ & $n$ & $\%$ & $n$ & $\%$ & $n$ & $\%$ & $n$ & $\%$ & & \\
\hline $\begin{array}{l}\text { I can practice grammar tasks } \\
\text { using the Leam English } \\
\text { Grammar application in all } \\
\text { locations }\end{array}$ & 0 & $0.00 \%$ & 1 & $3.70 \%$ & 1 & $3.70 \%$ & 4 & $14.80 \%$ & 21 & $77.80 \%$ & 4.67 & Strongly Agree \\
\hline $\begin{array}{l}\text { The Learn English Grammar } \\
\text { application was easy to use on }\end{array}$ & 0 & $0.00 \%$ & 0 & $0.00 \%$ & 4 & $14.80 \%$ & 8 & $29.60 \%$ & 15 & $55.60 \%$ & 4.41 & Strongly Agree \\
\hline
\end{tabular}




\begin{tabular}{|c|c|c|c|c|c|c|c|c|c|c|c|c|}
\hline my mobile device & & & & & & & & & & & & \\
\hline $\begin{array}{l}\text { I found the Learn English } \\
\text { Grammar application activities } \\
\text { very clear }\end{array}$ & 0 & $0.00 \%$ & 0 & $0.00 \%$ & 6 & $22.20 \%$ & 10 & $37.00 \%$ & 11 & $40.70 \%$ & 4.19 & Agree \\
\hline $\begin{array}{l}\text { I needed technical support to } \\
\text { upload the application * }\end{array}$ & 9 & $33.30 \%$ & 9 & $33.30 \%$ & 5 & $18.50 \%$ & 1 & $3.70 \%$ & 3 & $11.10 \%$ & 3.74 & Disagree \\
\hline $\begin{array}{l}\text { I found the items in the Learn } \\
\text { English Grammar application } \\
\text { difficult* }\end{array}$ & 7 & $25.90 \%$ & 8 & $29.60 \%$ & 6 & $22.20 \%$ & 4 & $14.80 \%$ & 2 & $7.40 \%$ & 3.52 & Disagree \\
\hline \multicolumn{11}{|c|}{ Usability } & 4.10 & Agree \\
\hline $\begin{array}{l}\text { Using the Learn English } \\
\text { Grammar application is a good } \\
\text { way to learn English Grammar }\end{array}$ & 1 & $3.70 \%$ & 0 & $0.00 \%$ & 2 & $7.40 \%$ & 7 & $25.90 \%$ & 17 & $63.00 \%$ & 4.44 & Strongly Agree \\
\hline $\begin{array}{l}\text { In general, the Leam English } \\
\text { Grammar application helped } \\
\text { me improve my English } \\
\text { grammar }\end{array}$ & 1 & $3.70 \%$ & 1 & $3.70 \%$ & 4 & $14.80 \%$ & 11 & $40.70 \%$ & 10 & $37.00 \%$ & 4.04 & Agree \\
\hline $\begin{array}{l}\text { The Learn English Grammar } \\
\text { application was helpful for } \\
\text { revising the grammatical points } \\
\text { in the textbook }\end{array}$ & 2 & $7.40 \%$ & 0 & $0.00 \%$ & 6 & $22.20 \%$ & 14 & $51.90 \%$ & 5 & $18.50 \%$ & 3.74 & Agree \\
\hline $\begin{array}{l}\text { Using the Learn English } \\
\text { Grammar application helped } \\
\text { me to apply the grammar } \\
\text { knowledge in writing and } \\
\text { speaking tasks }\end{array}$ & 2 & $7.40 \%$ & 1 & $3.70 \%$ & 6 & $22.20 \%$ & 11 & $40.70 \%$ & 7 & $25.90 \%$ & 3.74 & Agree \\
\hline $\begin{array}{l}\text { The practice with the Learn } \\
\text { English Grammar application } \\
\text { helped me to do better in the } \\
\text { Grammar examinations }\end{array}$ & 3 & $11.10 \%$ & 2 & $7.40 \%$ & 6 & $22.20 \%$ & 11 & $40.70 \%$ & 5 & $18.50 \%$ & 3.48 & Agree \\
\hline $\begin{array}{l}\text { I needed more explanation } \\
\text { from my teacher on points of }\end{array}$ & 0 & $0.00 \%$ & 4 & $14.80 \%$ & 9 & $33.30 \%$ & 10 & $37.00 \%$ & 4 & $14.80 \%$ & 2.48 & Agree \\
\hline
\end{tabular}




\begin{tabular}{|c|c|c|c|c|c|c|c|c|c|c|c|c|}
\hline grammar* & & & & & & & & & & & & \\
\hline $\begin{array}{l}\text { Face-to-face instructions is } \\
\text { more helpful for learning } \\
\text { points of grammar* }\end{array}$ & 0 & $0.00 \%$ & 8 & $29.60 \%$ & 4 & $14.80 \%$ & 7 & $25.90 \%$ & 8 & $29.60 \%$ & 2.44 & Agree \\
\hline \multicolumn{11}{|c|}{ Effectiveness } & 3.48 & Agree \\
\hline $\begin{array}{l}\text { I enjoyed using the Learn } \\
\text { English Grammar App }\end{array}$ & 2 & $7.40 \%$ & 0 & $0.00 \%$ & 2 & $7.40 \%$ & 8 & $29.60 \%$ & 15 & $55.60 \%$ & 4.26 & Strongly Agree \\
\hline $\begin{array}{l}\text { Using the Learn English } \\
\text { Grammar App is time } \\
\text { consuming* }\end{array}$ & 10 & $37.00 \%$ & 5 & $18.50 \%$ & 4 & $14.80 \%$ & 4 & $14.80 \%$ & 4 & $14.80 \%$ & 3.48 & Disagree \\
\hline $\begin{array}{l}\text { The wireless internet } \\
\text { connection was poor* }\end{array}$ & 3 & $11.10 \%$ & 8 & $29.60 \%$ & 12 & $44.40 \%$ & 4 & $14.80 \%$ & 0 & $0.00 \%$ & 2.63 & $\begin{array}{l}\text { Neither Agree/ } \\
\text { Nor Disagree }\end{array}$ \\
\hline \multicolumn{11}{|c|}{ Satisfaction } & 3.46 & Agree \\
\hline \multicolumn{11}{|c|}{ Perceptions of Learn English Grammar App } & 3.68 & Agree \\
\hline
\end{tabular}

*The expected answers to these questions are in reverse to other questions.

Table 6 Ranked Order of Themes (Highest to lowest)

\begin{tabular}{|l|r|r|}
\hline \multicolumn{1}{|c|}{ Theme } & \multicolumn{1}{|c|}{ Mean } & Std. Deviation \\
\hline Usability & 4.10 & 0.64 \\
\hline Effectiveness & 3.48 & 0.74 \\
\hline Satisfaction & 3.46 & 0.73 \\
\hline $\begin{array}{l}\text { Total Scale: Perceptions of the Learn English } \\
\text { Grammarapplication }\end{array}$ & 3.68 & 0.59 \\
\hline
\end{tabular}




\section{Macrothink}
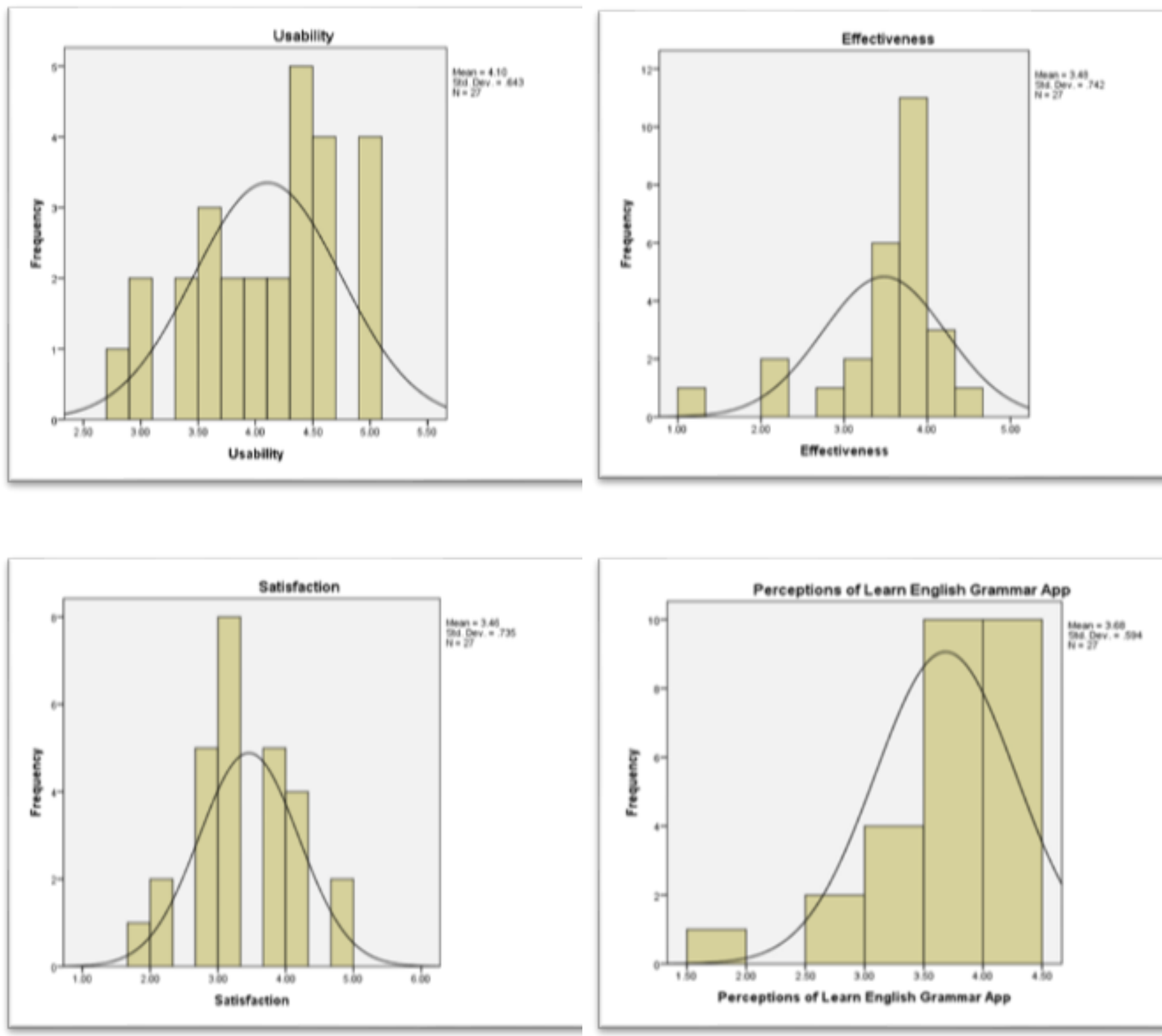

Figure 1. Distribution of agreements for each theme and the total scale

\subsection{Teachers' reflections}

The qualitative data results of the teachers' reflections revealed that the control group teacher reported students were concerned about grammar rules and experienced some issues in differentiating between tenses and found grammar to be a challenging subject:

I noticed that differentiating between the tenses is a bit difficult for them.

Ifeel that they are a bit worried and nervous about whether their answers are right or wrong. Their overall grammar knowledge is somewhat limited, and they need a lot of practice.

They did tell me that the grammar in level 103 was particularly difficult. 
On the other hand, the reflections of the teachers of the experimental group showed that the students were interested in using the application and that it increased their engagement and motivation to learn grammar. The teachers felt that the application was helpful, stating that:

I think the application helped the students to become more engaged and motivated.

They became more engaged and started asking questions.

The students were very interested and one of them said she used the app twice at home and found it very useful. Another student replied that using this app is really nice because we don't have any pressure, and no grades.

However, the teacher reported one negative point, which was that not all students found the app's instructions to be sufficiently clear.

The only disadvantage is that the app is a bit difficult to use for some students. They don't know whether to press 'done', or 'next'.

\section{Discussion}

This section discusses the findings in respect to the research questions and compares them to the related literature.

$R Q 1$. Were there any statistically significant differences between the achievement of the experimental and control groups in relation to grammar learning?

This study found that integrating the Learn English Grammar application into the grammar lessons of Saudi preparatory year female EFL students' led to a significant improvement in their performance. These findings are supported by those of Kabooha (2016), who noted that the majority of students and teachers found YouTube helpful for improving their English vocabulary. She also identified a significant difference in the results of the pre- and post-test, in favor of the experimental group, thus indicting an improvement in the students' vocabulary as a result of using YouTube. This is consistent with Cabrera et al. (2018), who examined the impact of the online tool Pixton (which enables teachers and students to create comic strips for learning and teaching purposes) on high school students in Ecuador. The study found that students in the experimental group implementing Pixton improved significantly in comparison to the control group receiving traditional forms of instruction.

Hossain (2018) explored university EFL learners' use of smartphones applications to learn English in Bangladesh, stating that $82.42 \%$ employed English language applications, compared to those who did not (17.58\%). In addition, $86.66 \%$ of the students agreed that 
such applications helped them to learn English in a rapid and simpler manner and that they facilitated the learning of all language skills. These conclusion concur with relevant findings in the Saudi context exploring the influence of mobile applications on EFL learning. Hazaea and Alzubi (2016) investigated the impact of mobile applications on supporting reading practices, determining an improvements in the reading skill of students when they used WhatsApp outside the classroom to: (1) reproduce text and send it to their teachers: (2) share difficult vocabulary and sentences, in order to clarify meanings with their classmates; and (3) search the Internet to locate new reading and comprehension texts.

$R Q$ 2. What were Saudi EFL female foundation year students' perceptions towards the integration of Learn English Grammar app in classroom in learning grammar?

The findings from the post-questionnaire suggested that the majority of students perceived the Learn English Grammar application as beneficial for the acquisition of grammar. The majority viewed it as being easy to use and widely accessible. In a study of the impact of mobile phones on students' English language learning in a university in Saudi Arabia, Nalliveettil and Alenazi (2016) found that all teachers, along with the majority of undergraduate students, perceived smartphones to be an effective aid for teaching and learning English. 75\% of these students possessed smartphones and used them for learning English, while 87\% used English electronic dictionaries to look up the meaning and spelling of difficult vocabulary when required. Moreover, the authors found that teachers and students found smartphones to be accessible and capable of being utilized for learning English both within and outside the classroom. Approximately half the students in this study responded that they found the Learn English Grammar application easy and fun to use, as well as helping them to learn grammar. Similarly, Gafni et al. (2017) found that voluntary users of the Duolingo application for language learning recorded a higher level of positive responses, finding the application easy to integrate, as well as increasing the enjoyment of the learning experience and improving their language learning. These results support the notion that there is a need to increase the use of mobile phones in classroom due to their advantages.

Findings from the post-questionnaire data suggested that the majority of the students perceived the Learn English Grammar app to be effective for the practice of grammar, including the grammatical rules in the textbook capable of enabling them to improve their examination results. However, a small number stated that they found regular face-to-face instruction to be more helpful. This result may be due to students being more accustomed to teacher-centered instructions, particularly when it comes to the teaching of grammar. Most of the preparatory year students experienced grammar as challenging and were also unaccustomed to using smartphones in their classrooms, as most of their teachers prohibited their use in class. This encouraged both students and teachers to develop an awareness of the potential benefits of mobile applications for language teaching and learning. Ariffin et al.'s (2016) qualitative study in Malaysia exploring the attitudes of trainee teachers towards the barriers and enablers of mobile generated content found positive attitudes towards the use of mobile phones in generating learning content. However, it also identified several obstacles, in particular a lack of knowledge of the benefits, with many trainees stressing that they preferred the use of traditional instruction. 
The results of the current study revealed that students found the Learn English Grammar application to be an enjoyable and satisfying learning tool. This is in line with the findings of Suwantarathip and Orawiwatnakul (2015), who identified the positive attitude of EFL first year university students towards the use of SMS to increase their vocabulary. They responded that the use of SMS increased their engagement with learning vocabulary, and that it created an enjoyable and flexible learning environment, i.e. they were able to send an assignment to their teacher by means of SMS and receive instant feedback. In the Saudi context, Kabooha and Elyas (2018) found that the majority of students stated that using YouTube in the classroom for learning new vocabulary created an engaging and motivating learning atmosphere that improved learning. This could be due to the attachment of the current generation to technology in general, and their smartphones in particular. This should encourage teachers and educators to take advantage of the use of such technology and increase their awareness of its potential in relation to EFL instruction. They should also consider creating learning experiences that are both meaningful and engaging. Kim et al. (2013) suggested that teachers should be made aware of the need to create mobile activities containing a pedagogical content related to the objectives of the subject, while at the same time ensuring they are both easy and enjoyable.

On the other hand, some students found the wireless connection to be poor, which can be attributed to most connecting their smartphones to the university's Wi-Fi, which can prove unreliable, but is free, as opposed to the expense of using 4G. Ariffin (2016:55) found that trainee teachers reported a number of technical obstacles for generating learning activities through mobile phones, including issues with batteries running out, while one complained that the wireless connection was very slow, making it difficult to complete a task, particularly when it came to video conferencing.

$R Q$ 3. What was teachers' reflective view of integrating Learn English Grammar application in learning grammar?

The results of the teachers' reflections demonstrated that those teaching the experimental group found that the integration of the application helped to increase students' engagement and motivation, which was in accord with the students', enjoyment of using the application. This is consistent with Kabooha (2016), in particular in relation to the teachers' views of the benefits of integrating YouTube into the teaching of vocabulary. The researcher found that teachers believed that this improved the meaningful and active engagement of their students in class discussions. On the other hand, the teacher of the control group noted that her students experienced difficulties in grasping these grammatical rules. This study highlighted that teachers who encourage their students to take advantage of mobile phones applications for EFL learning can find their classrooms to be enjoyable places, as the motivation and engagement of students can be increased, resulting in more fle xible learning. Cabrera et al. (2018) found that the majority of teachers expressed positive views of the Pixton application for teaching grammar and vocabulary, considering the application to be beneficial in enhancing students' motivation to learn. 


\section{Conclusion}

This study examined the influence of integrating the Learn English Grammar application into the grammar lessons of preparatory year students, including their perceptions of its benefit. The findings of the study suggest that the students employing the application in the classroom improved their grammar knowledge in comparison to students taught by means of traditional instruction. These positive findings suggest that mobile learning applications can contribute to EFL learning and teaching. In addition, mobile phones can offer many learning applications capable of creating a pleasant and productive learning environment. Teachers can exploit the pedagogical practice of using mobile applications for all integrated skills, i.e. writing, speaking, reading and listening. However, it is a selective process that should be undertaken with full awareness of the learning objectives. This has the benefit of increasing teachers' awareness of the kind of mobile activities capable of being integrated into their lessons, in order to achieve positive learning outcomes.

The findings also highlight that the students in the current study had a positive attitude towards the use of the Learn English Grammar application, perceiving it to be usable, effective and a satisfying tool for grammar learning. This suggests that students recognize the advantages of using mobile applications for EFL learning, including accessing learning materials from any location and regardless of the time of day. The study also confirmed that mobile applications can increase the enjoyment of the learning environment. This is largely due to most members of the younger generation being familiar with and constant users of mobile phones, which can thus be implemented for learning proposes.

This study contributes to the literature concerning mobile learning applications in the EFL Saudi context, and in particular to the use of EFL mobile learning applications for learning grammar. It also highlights students' attitudes towards the use of mobile applic ations for EFL learning. This study has much strength, however it also contains a number of limitations. Firstly, the study sample was relatively small (i.e. fifty-two students) and (two teachers). Secondly, the study was undertaken over the period of a single module (i.e. over seven weeks). This was insufficient time to allow students to practice the application, and so experience additional activities, so enriching the study and providing additional insights into students' use of the Learn English Grammar application. Thirdly, the study was limited to female students, due to the constraints of Saudi culture that does not permit male and female students to mingle in one campus. Finally, this research did not cover the constraints and enablers of using mobile applications for EFL learning.

The study therefore recommends that future research should focus on longitudinal studies examining the use of mobile learning applications by both teachers and students, along with their attitudes towards such applications, and methods open to teachers to provide their students with mobile activities to match their needs. It also recommended that future research should observe the constraints and enablers relating to the use of mobile applications for EFL learning. Such research has the potential to give educators and decision-makers valuable insights into the factors capable of ensuring improved learning outcomes. 


\section{References}

Alshammari, R., Parkes, M. \& Adington, R. (2017). Using WhatsApp in EFL instruction with Saudi Arabian university students. Arab World English Journal (AWEJ), 8(4), .68-84. Retrieved from: http//awej.org/images/AllIssues/Volume8/Volume8number4december/5.pdf

Al-Wasy, B., Q. \& Mahdi, H., S. (2016). The Effect of Mobile Phone Applications on Improving EFL Learners' Self-editing. Journal of Education and Human Development, 5(3), 149-157.

Alwehaibi, H. O. (2015). The impact of using YouTube in EFL classroom on enhancing EFL students' content learning. Journal of College Teaching and Learning, 12(2), 121-126.

Ariffin, S. A. \& Idris, S. (2016). Challenges and opportunities for students-generated mobile content in Malaysia. International Journal of Mobile and Blended Learning, 8(3), 93-104.

Cabrera, P., Castillo, L., Gonzalez, P., Quinonez, A. \& Ochoa, C. (2018). The Impact of Pixton for teaching grammar and vocabulary in EFL Ecuadorian context. Teaching English with Technology, 18(1), 53-76.

Chen, K.TC. (2017). Examining EFL instructors' and students' perceptions and acceptance toward M- learning in higher education. Springer Berlin Heidelberg, University Access, 16(4), 967-976. Retrieved from: https://doi.org/10.1007/s10209-016-0494-8

Chen, Y., Carger, C. L. \& Smith, T. J. (2017). Mobile assisted narrative writing practice for young English language learners from a fund of knowledge approach. Language Learning and Technology, 21(1), 28-41.

Cohen , L., Manion, L., \& Morrison,K. (2011). Research Methods in Education. London: Routledge.

Costa, R., S. \& Han, T. (2017). The effect of using mobile application on EFL learners' beliefs about language learning (BALL). International Journal of Developmental and Educational Psychology, 2(1), 229-138. Retrieved from: http://www.redalyc.org/pdf/3498/349853220023.pdf

Gafni, R., Achituv, D. B. \& Rachmani, G., J. (2017). Learning foreign language using mobile applications. Journal of International Technology Education Research, 16, 301-317.

Hazaea, A., N. \& Alzubi, A., A. (2016). The effectiveness of using mobile on EFL learners' reading practices in Najran University. English Language Teaching, 9(5), 8-21.

Hossain, M. (2018). Exploiting Smartphones and Apps for Language Learning: A Case Study with EFL Learners in a Bangladeshi University. Review Public Administration and Management, 6(1). Retrieved from: https://doi.org/10.4172/2315-7844.1000241, 1-5

Kabooha, R., H. (2016). Using movies in EFL classroom: A study conducted at the English Language institute (ELI), King Abdul-Aziz University. English Language Teaching, 9(3), 248-257. 
Kabooha, R., H. \& Elyas, T. (2018). The Effect of YouTube in multimedia instruction for vocabulary learning: Perceptions of EFL students and teachers. English Language Teaching, 11(2), 72-81.

Kétyi, A. (2013). Using Smart Phones in Language Learning - A pilot study to turn CALL into MALL. In L. Bradley and S. Thouësny (Eds.), 20 Years of EUROCALL: Learning from the Past, Looking to the Future. Proceedings of the 2013 EUROCALL Conference, Évora, Portugal (pp. 129-134). Dublin/Voillans.

Kim, D., Rueckerk, D., Kim, D-J. \& Seo D. (2013). Students' perceptions and experiences of mobile learning. Language Learning and Technology, 17(3), 52-73.

Liu, Q., \& He, X. (2014). Using mobile apps to facilitate English learning for college students in China. Bachelor's Thesis in informatics. University of Boras, Schools of Business and IT. Retrieved from: http://www.diva-portal.org/smash/get/diva2:896787/FULLTEXT01.pdf

Mart, C. T. (2013). Grammar in context: why and how? Theory and Practice in Language Studies, 3(1), 124-129. from: http://www.academypublication.com/is sues/past/tpls/vo103/01/18.pdf

Nalliveettil, G. M., \& Alenazi, T.H.K (2016). The impact of mobile phones on English language learning: Perceptions of EFL undergraduates. Journal of Language Teaching and Research, 7(2), 264-272.

Nushi, M. \& Eqbali, M. H. (2018). 50LANGUAGES: A mobile language learning application (App Review). Teaching English with Technology, 18(1), 93-104.

Rajayi, S., Poorahmadi, M. \& Poorahmadi, M. (2018). The impact of teaching vocabulary through the 'Kik' application on improving intermediate EFL learner's vocabulary Learning. International Journal of English Language Teaching, 5(1), 22-28.

Rodríguez, P. Arús, J., \& Calle, C. (2013). The Use of Current Mobile Learning Applications in EFL. Social and Behavioral Sciences, 103(2013), 1189-1196.

Suwantarathip, O. \& Orawiwantnakul, W. (2015). Using mobile- assisted exercises to support students' vocabulary skill development. The Turkish Online Journal of Education Technology, 14(1), 163-171.

Wang, S. \& Smith, S. (2013). Reading and grammar learning through mobile phones. Language Learning and Technology, 17(3), 117-134.

\section{Copyright Disclaimer}

Copyright for this article is retained by the author(s), with first publication rights granted to the journal.

This is an open-access article distributed under the terms and conditions of the Creative Commons Attribution license (http://creativecommons.org/licenses/by/3.0/). 